\title{
THE INFLUENCE OF PORE GEOMETRY IN CP TI-IMPLANTS - A CELL CULTURE INVESTIGATION
}

\author{
R. Stangl ${ }^{1 *}$, B. Rinne ${ }^{2}$, S. Kastl ${ }^{1}$ and C. Hendrich ${ }^{3}$
}

\begin{abstract}
${ }^{1}$ Department of Traumatology, Surgical Clinic, University of Erlangen, ${ }^{2}$ Department of Experimental Dental Medicine, University of Würzburg, and ${ }^{3}$ Department of Orthopaedics, University of Würzburg, Germany
\end{abstract}

\begin{abstract}
Biocompatibility testing of differently structured titanium implants was performed using an in vitro test system of a newly established human fetal osteoblastic cell line (hFOB 1.19). Cell adhesion of osteoblastic cells on the different porous geometries and the suitability of a copper vapor laser system for surface structuring was tested with the following parameters: cell-number, cell viability, alkaline phosphatase expression.

The analysis of the cell culture results demonstrated that $25 \mu \mathrm{m}$ and $200 \mu \mathrm{m}$ porous geometries showed similar or even better results than the negative control of polystyrene; there was no sign of toxic effects. However, the $100 \mu \mathrm{m}$ porous geometry showed an impressive negative influence on the calculated parameters. The reason for this effect is unclear.

The series with $50 \mu \mathrm{m}, 300 \mu \mathrm{m}, 400 \mu \mathrm{m}$ and $500 \mu \mathrm{m}$ showed a comparable, intermediate effect on the cell culture with respect to the different parameters. However, the results were worse than with the 25 and $200 \mu \mathrm{m}$ porous geometry. In conclusion, the $25 \mu \mathrm{m}$ and $200 \mu \mathrm{m}$ porous geometry seems to have the most positive effect on the human osteoblastic cell line hFOB 1.19.
\end{abstract}

Key Words: Topography, copper vapor laser, porous geometry, cell culture, titanium, osteoblasts.

\author{
*Address for correspondence: \\ Richard Stangl \\ Unfallchirurgische Abteilung der Chirurgischen \\ Universitätsklinik Erlangen \\ Krankenhausstraße 12 \\ 91054 Erlangen
}

Telephone Number: 00499131 - 8533296

Fax Number : 00499131 - 8533300

e-mail: richard.stangl@web.de

\section{Introduction}

The success of cementless total hip arthroplasty is dependent both on the measure of primary mechanical stability, related to the precise shaping of the bony cavity, and on secondary stability achieved through the direct adsorption of bone cells at the implant surface. Such secondary stability is affected by the material's biocompatibility, the design of the implant components, the osteogenic potential of the accommodating bone, the surgical technique and on the stress forces applied at the bone-implant interface (Skalak, 1983). It is completed in two phases. The initial bony ingrowth into the implant surface is subsequently followed by "bone remodeling", an adaptation to the new weight-bearing situation (Morscher, 1987; Søballe, 1993; Thomas and Cook, 1985). Both in vivo and in vitro studies suggest that osteoblasts independently from mechanical stresses favor ingrowth into rough and porous surfaces while a smooth surface even with biocompatible materials impedes the initial adsorption of osteoblasts (Schmitz, 1991). Copper vapor laser technology for structuring of micromaterials has allowed for the development of a porous surface structure with pore diameters up to $1-5 \mu \mathrm{m}$. This has permitted the development of defined, reproducible and economical surface topographies (Bergmann et al., 1994). In the following in vitro study we examine the application of the copper vapor laser system in structuring the implant surface and discuss the influence of pore geometry at the cell culture level.

\section{Materials and Methods}

The human fetal osteoblast cell line hFOB 1.19 used was obtained from Dr. Thomas C. Spelsberg, Mayo-Clinic, Rochester, MN, USA. This cell line is transfected with a gene that codes for the temperature sensitive mutant (tsA58), SV $40 \mathrm{~T}$-antigen, together with a gene coding for gentamycin resistance (Harris et al., 1995). Osteoblasts were subcultured to a $12 / 14$ cycle. Cells were cultured in DMEM (Dulbecco's modified essential medium) with $10 \%$ FCS (Fetal Calf Serum). The medium was changed every second day until the end of the experimental period on days 12 to 17 . The laser-structured materials to be tested were incubated in 24 well plates with 50,000 cells/well at a temperature of $34^{\circ} \mathrm{C}$ in a humidified incubator containing $5 \% \mathrm{CO}_{2}$. The hFOB 1.19 cell lines were maintained in the DMEM medium until a confluent layer of cells was obtained. At that time, in most cases approximately on day 
3, the medium was changed to BGJb medium (Fitton Jackson modification) (Hendrich et al., 1996a,b).

After removal of the medium the 24 well plates were rinsed two times with $1 \mathrm{ml}$ PBS (phosphate-buffered saline) to withdraw the non-adherent cells. Additionally $0.5 \mathrm{ml}$ Trypsin/EDTA-solution was given to the cells for $5 \mathrm{~min}$ utes. The trypsin effect was stopped using $0.5 \mathrm{ml}$ of the culture medium followed by aspiration of the cells for ten times using an Eppendorf pipette. It could be demonstrated randomly by use of the Live-Dead Viability Assay (Molecular Probes, Eugene, OR, USA) that no vital cells remained on the surface. Cell number was determined using an electronic cell counter (CASY 1, Mod. TTC, Schärfe System, Reutlingen, Germany). The system works according to the resistance principle combined with an additional pulse area analysis and a signal scanning frequency of 1 MHz. Equipped with a multichannel analyzer with 512000 channels, this system allows an extremely sensitive, reproducible, and nearly error free analysis of the size distribution of a whole cell population within $1 \mathrm{~min}$. For analysis a $100 \mu \mathrm{L}$ aliquot of the cell sample was directly diluted 1:100 in a phosphate-buffered saline (PBS) based electrolytesolution and gently mixed. Then an exactly adjustable aliquot was automatically measured by the system (Seewöster and Lehmann, 1997).

Cell viability was demonstrated using the Live-DeadViability assay (Molecular Probes). The main principle of the test is to demonstrate the esterase activity in intact cells and the proof of cell membrane permeability. Intact cells incorporate the polyanionic fluorescent dye calcein-AM and metabolize the dye to a green fluorescing calcein. The red dye ethidium-homodimer penetrates destroyed membranes and binds nucleic acids. According to this theory intact cells reflect green, whereas dead cells reflect red.. The test procedure was performed using $4 \mu \mathrm{M}$ ethidiumhomodimer and $2 \mu \mathrm{M}$ Calcein-AM in a PBS-solution, each of them prepared from a fresh stock solution. After 5 days in cell culture the medium was suctioned off. Unspecific esterases of the FCS-medium were removed by rinsing the plates two times with PBS. Subsequently, the cultured cells were covered with $100 \mu$ l test solution and incubated for 20 minutes at room temperature. Fluorescence microscopy was performed with a Zeiss axioscope (Zeiss, Oberkochen, Germany) using a blue filter with a wave-length of 450 and $490 \mathrm{~nm}$. Photodocumentation was done at 50-, 100and 200 times magnification with a Zeiss MC 63 exposure automatic machine and a scotch chrome daylight film $800 / 3200 \mathrm{P}$ at 800 ASA.

Cell viability of the implant adherent osteoblasts, which demonstrates ongoing mitochondrial metabolism, was examined using the MTT-test method. Here the color of the WST-reagent was changed to a red color by mitochondrial dehydrogenase (succinate dehydrogenase) in the citric acid cycle (Formazan) or due to a reaction of NADH at the plasma membrane and the presence of this was determined photometrically at 450nm (Ishiyama et al., 1995). This investigation was completed using the WST-1 test (Boehringer Mannheim, Germany). Incubation of the osteoblasts with $500 \mu \mathrm{L}$ DMEM and $50 \mu \mathrm{l}$ WST-1 reagent at $34^{\circ} \mathrm{C}$ in a humidified incubator containing $5 \% \mathrm{CO}_{2}$ was completed for 30 minutes. Determination of the quantity of formed Formazan was performed using an ELISA reader (SLT, Crailheim, Germany) read at a wavelength of 450nm (Liu et al., 1995).

Alkaline phosphatase activity was determined spectrophotometrically in the ELISA reader (SLT, Crailheim, Germany) at a wavelength of $405 \mathrm{~nm}$, related to the amount of p-nitrophenols. The method of Bradford (Bradford, 1976) was used to measure the total protein thereby permitting the calculation of specific alkaline phosphatase activity (U/ $\mathrm{mg})$.

Scanning electron microscopy (SEM) examination of the various structured surface areas $(100-2000$ magnification) was done after 1.5 culture days. After removal of the culture media the cells were rinsed for $1 \mathrm{~min}$ with Sörensen Buffer ( $\mathrm{pH}$ 7.4). Primary fixation of the cells was carried out in $6.25 \%$ glutaraldehyde for $15 \mathrm{~h}$. Rinsing was done 5 times for 5 minutes in Sörensen-Buffer ( $\mathrm{pH}$ 7.4). After primary fixation, the dehydration procedure was done using 30\% ethanol for $15 \mathrm{~min}, 50 \%$ ethanol for $20 \mathrm{~min}$, $75 \%$ ethanol for $30 \mathrm{~min}, 100 \%$ ethanol for $45 \mathrm{~min}$ and $100 \%$ ethanol 5 times for $30 \mathrm{~min}$. Finally the samples were critical-point dried. The specimen were mounted onto stubs with silver paint and coated with $8 \mathrm{~nm}$ of gold. Scanning electron microscopical examination of the specimen was executed with a Zeiss DSM 940 with an accelerating voltage of 1 to $30 \mathrm{kV}$.

Implant: The titanium slices were obtained from Brehm Co., Weisendorf, Germany. Outer surface structuring was produced using a copper vapour laser system with a mean output of $120-140 \mathrm{~W}$, a maximum pulse-frequency of 6.5 $\mathrm{kHz}$ (ATZ-EVUS, Vilseck, Germany) and with nanosecond precision control of the stimulation point using a so called Master-Timing-System. Lasers with a fixed wavelength of either 511 or $578 \mathrm{~nm}$ were used. The pore size was measured on the cross sections of the specimens using backscattered scanning electron microscopy. The influence of variations of the parameter pulse frequency (fp), pulse power $(\mathrm{Pp})$, focal distance $(\mathrm{F})$, focus position $(\mathrm{z})$ and number of pulses on the drill hole geometry was tested (Mayerhofer, 1997; Bergmann et al., 1996). The beard around the drill-holes was grinded using grind paper with a roughness of 1200 and 2400. Subsequently, the specimen were cleaned in an ultrasound bath and sterilized according to the FDA 100 criteria (Food and Drug Administration, Rockville, MD, USA) including gamma-sterilization at $28 \mathrm{kV}$. Surface characteristics of the rough-blasted implants $\left(\mathrm{Al}_{2} \mathrm{O}_{3}\right.$ beads $\left.500-710 \mu \mathrm{m}\right)$ were measured using a fine needle perthometer ( $\mathrm{Fa}$. Mahr, Göttingen, Germany). Additionally, the surface characteristics of the laser-structured implants and the rough-blasted implants were analyzed using $3 \mathrm{D}$ analysis by laser electron microscopy (Leica Microsystems, Heidelberg, Germany).

50 round, one-sided, laser structured titanium slices (cpTi) were manufactured with an outer diameter of $15.5 \mathrm{~mm}$ (surface area $=188.6 \mathrm{~mm}^{2}$ ), a central hole $\left(\right.$ area $\left.=0.8 \mathrm{~mm}^{2}\right)$ and an open pore surface area with a defined pore-diameter, -depth, -geometry and -interpore spacing (Table 1).

Each titanium slice had a thickness of $2 \mathrm{~mm}$. The interpore distance was determined from the midpoint poreto-pore distance. The ground area of each titanium slice 


\begin{tabular}{|l|c|c|c|}
\hline Titanium & $\begin{array}{c}\text { Pore-depth } \\
\text { in } \mu \mathrm{m}\end{array}$ & $\begin{array}{c}\text { Pore-diameter } \\
\text { in } \mu \mathrm{m}\end{array}$ & $\begin{array}{c}\text { Pore-to-pore distance } \\
\text { in } \mu \mathrm{m}\end{array}$ \\
\hline $500 \mu \mathrm{m}$ & 500 & 500 & 1500 \\
\hline $400 \mu \mathrm{m}$ & 400 & 400 & 1200 \\
\hline $300 \mu \mathrm{m}$ & 300 & 300 & 900 \\
\hline $200 \mu \mathrm{m}$ & 200 & 200 & 400 \\
\hline $100 \mu \mathrm{m}$ & 100 & 100 & 200 \\
\hline $50 \mu \mathrm{m}$ & 50 & 50 & 100 \\
\hline $25 \mu \mathrm{m}$ & 25 & 25 & 50 \\
\hline Polystyrene & \multicolumn{2}{|l}{} \\
\hline
\end{tabular}

Table 1. Porous geometry on the titanium discs

excluding the central hole was $187.9 \mathrm{~mm}^{2}$.

Mathematical analysis was performed to determine the increase in porous surface area available for cell growth for the various pore sizes. This was based on the pore geometry (Total surface area $=$ structured surface area + area of the pore wall). The $200 \mu \mathrm{m}$ pore has a cylindrical form (increase in surface area factor, magnification factor, (MF), 1.78), whereas all other pores had either a conical or elliptical form. The increase in surface area available for growth was smallest in the case of a conical geometry (MF, 0.31), whereas with an elliptical shape there was an MF of 0.71 . The shape of both the 25 and $50 \mu \mathrm{m}$ pores can only be considered approximately as either elliptical or conical and was assigned an MF of 0.5 (Table 2).

\begin{tabular}{|c|c|c|c|c|c|c|c|}
\hline Surface/pore-geometry & $25 \mu \mathrm{m}$ & $50 \mu \mathrm{m}$ & $100 \mu \mathrm{m}$ & $200 \mu \mathrm{m}$ & $300 \mu \mathrm{m}$ & $400 \mu \mathrm{m}$ & $500 \mu \mathrm{m}$ \\
\hline Number of pores / titanium disc & 75160 & 18790 & 4697 & 1174 & 231 & 130 & 84 \\
\hline \multicolumn{8}{|l|}{ Additional surface area dependent } \\
\hline on the porous geometry in $\mathrm{mm}^{2}$ & & & & & & & \\
\hline cylindrical (MF 1.78) & 147.5 & 147.5 & 147.5 & 147.5 & 65.3 & 65.3 & 65.9 \\
\hline conical (MF 0.31) & 45.7 & 45.7 & 45.7 & - & 20.25 & 20.25 & 20.34 \\
\hline elliptical (MF 0.75) & 110.6 & 110.6 & 110.6 & - & 48.97 & 48.97 & 49.42 \\
\hline mean (MF 0.5) & 73.75 & 73.75 & 73.75 & - & 32.65 & 32.65 & 32.95 \\
\hline
\end{tabular}

Table 2. Surface area and surface magnification of the titanium discs.

For each porous surface 2 to 3 independent readings were obtained for each of the defined parameters on alternate culture days (day 2, $4,6,8$, etc.). Mean values were calculated relative to the polystyrene standard value. Cell number, viability and alkaline phosphatase activity were calculated in relation to the polystyrene levels. Due to the small number of values a confirmatory statistic test was not indicated, whereas a certain difference was evident.

\section{Results}

The morphological behavior of osteoblasts at the cell-implant interface is the first qualitative parameter of implant biocompatibility. Osteoblasts on the $25 \mu \mathrm{m}, 50 \mu \mathrm{m}, 200 \mu \mathrm{m}$, $300 \mu \mathrm{m}, 400 \mu \mathrm{m}$ and $500 \mu \mathrm{m}$ porous surfaces were predominantly of an elongated, favorable cell formation. In Figure 1 we show osteoblast alignment at a pore. Such migration occurs possibly either due to a mechanical or a electrochemical effect. Cell numbers obtained on the laser-structured surface varied with surface topography (Figure 2). Table 3 shows the corresponding datasheet.

The highest cellular proliferation was obtained on titanium slices with a pore geometry of $50 \mu \mathrm{m}, 300 \mu \mathrm{m}, 400 \mu \mathrm{m}$ and $500 \mu \mathrm{m}$. These surfaces demonstrated a comparable or slightly better increase in cell growth than polystyrene controls. Cell number on the $50 \mu \mathrm{m}$ porous surface was lower

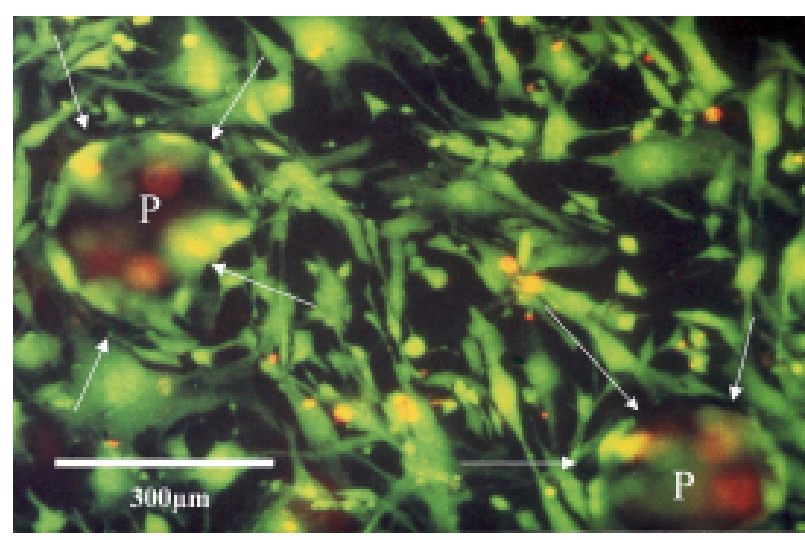

Figure 1. Cellular growth on a $300 \mu \mathrm{m}$ implant surface, day 4 in culture $(\mathrm{P}=$ pore $)$.

\section{Cell number}

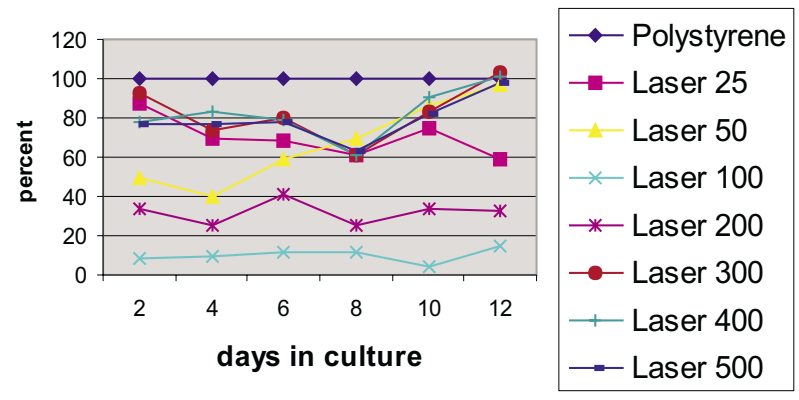

Figure 2. Influence of pore geometry on cell number (expressed as a $\%$ of the polystyrene control).

\begin{tabular}{|l|c|c|c|c|c|c|}
\hline $\begin{array}{l}\text { Type of } \\
\text { surface }\end{array}$ & Day 2 & Day 4 & Day 6 & Day 8 & Day 10 & Day 12 \\
\hline Polystyrene & 100 & 100 & 100 & 100 & 100 & 100 \\
\hline Laser 25 & $87(77-92)$ & $70(37-86)$ & $68(61-76)$ & $61(4-83)$ & $75(69-84)$ & $59(27-68)$ \\
\hline Laser 50 & $49(29-59)$ & $40(36-48)$ & $59(49-65)$ & $70(62-75)$ & $86(82-93)$ & $97(87-107)$ \\
\hline Laser 100 & $9(6-13)$ & $9(0-16)$ & $12(9-14)$ & $12(6-18)$ & $5(4-6)$ & $14(10-21)$ \\
\hline Laser 200 & $34(19-48)$ & $25(22-30)$ & $41(27-60)$ & $25(12-41)$ & $34(16-45)$ & $32(7-49)$ \\
\hline Laser 300 & $93(91-95)$ & $73(68-77)$ & $80(79-82)$ & $61(58-62)$ & $83(69-98)$ & $103(97-105)$ \\
\hline Laser 400 & $78(74-81)$ & $83(77-90)$ & $79(77-80)$ & $61(58-65)$ & $91(90-93)$ & $102(97-106)$ \\
\hline Laser 500 & $77(71-82)$ & $76(69-84)$ & $78(77-79)$ & $63(62-64)$ & $82(66-93)$ & $98(92-106)$ \\
\hline \multicolumn{7}{|l|}{ mean (min-max) in \% }
\end{tabular}

Table 3. Datasheet corresponding to Figure 2.

at earlier time points and thereafter continuously increased. Cell number on the $500 \mu \mathrm{m}$ porous surface was minimally lower than those on the $300 \mu \mathrm{m}$ and $400 \mu \mathrm{m}$ surfaces. Cell number on the $25 \mu \mathrm{m}$ surface did not reach the level of the $50 \mu \mathrm{m}, 300 \mu \mathrm{m}, 400 \mu \mathrm{m}$ or $500 \mu \mathrm{m}$ pores, although cell numbers were higher at early time points. The implant series with a $100 \mu \mathrm{m}$ porous structure demonstrated the poorest cellular development. Although titanium slices with a $200 \mu \mathrm{m}$ pore structure supported more cell development when compared with $100 \mu \mathrm{m}$ surface, this proved to be significantly less optimal than titanium slices with $50 \mu \mathrm{m}$, $300 \mu \mathrm{m}, 400 \mu \mathrm{m}$ and $500 \mu \mathrm{m}$ pores.

Results of cell viability determinations correlate with the results of the cellular counts. However, relative activity of cell viability is influenced by the amount of cells. Figure 3 and Table 4 show the relative amount of cell viability in relation to the number of cells. 


\section{Cell viability}

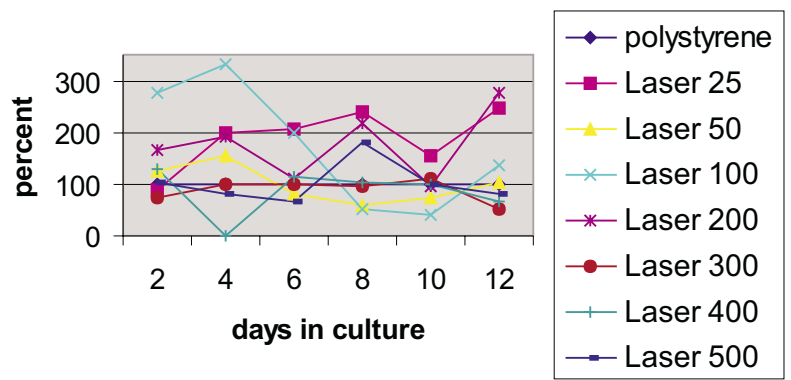

Figure 3. Relative cellular vitality (expressed as a $\%$ of the polystyrene control).

\begin{tabular}{|l|c|c|c|c|c|c|}
\hline $\begin{array}{l}\text { Type of } \\
\text { surface }\end{array}$ & Day 2 & Day 4 & Day 6 & Day 8 & Day 10 & Day 12 \\
\hline Polystyrene & 100 & 100 & 100 & 100 & 100 & 100 \\
\hline Laser 25 & 87 & 198 & 206 & 241 & 156 & 247 \\
\hline Laser 50 & 124 & 155 & 81 & 59 & 74 & 103 \\
\hline Laser 100 & 278 & 333 & 200 & 50 & 40 & 135 \\
\hline Laser 200 & 165 & 192 & 110 & 216 & 97 & 275 \\
\hline Laser 300 & 75 & 101 & 100 & 95 & 112 & 52 \\
\hline Laser 400 & 130 & - & 114 & 105 & 98 & 66 \\
\hline Laser 500 & 105 & 82 & 65 & 179 & 101 & 80 \\
\hline
\end{tabular}

Table 4. Datasheet corresponding to Figure 3.

Osteoblasts on the $25 \mu \mathrm{m}$ surfaces demonstrated the highest relative metabolic activity, followed by those on the $200 \mu \mathrm{m}, 300 \mu \mathrm{m}, 400 \mu \mathrm{m}$ and $500 \mu \mathrm{m}$ surfaces, respectively. However, cells on the $200 \mu \mathrm{m}$ titanium discs showed the highest activity at day 12 . Initially, cells on the titanium slices with a pore diameter of $100 \mu \mathrm{m}$ showed a relatively high cell viability (day 2 to 6 ), but in view of the small number of cells these results need careful interpretation. Titanium series with a surface pore diameter of $50 \mu \mathrm{m}$, $300 \mu \mathrm{m}, 400 \mu \mathrm{m}$ and $500 \mu \mathrm{m}$ behaved almost identically and viability values reached levels between those of the $25 \mu \mathrm{m}$ and the $100 \mu \mathrm{m}$ pore geometry between day 8 and 12 . Furthermore, cell viability on the different porous surfaces was better than on the polystyrene surface on the different test days. The $25 \mu \mathrm{m}$ and $200 \mu \mathrm{m}$ surfaces showed the most favorable relative cell viability.

Osteoblastic alkaline phosphatase activity is a recognized parameter of cellular differentiation on the implant surface. We observed that hFOB 1.19 cells on $50 \mu \mathrm{m}$ porous titanium surface show an optimal alkaline phosphatase activity after 12 days whereas those on the $25 \mu \mathrm{m}$ porous titanium slices reach maximum activity on day 8 (Figure 4, Table 5). These results were better than those of the polystyrene standard on every day. Cells on the $100 \mu \mathrm{m}$ porous titanium slices persistently show extremely low alkaline phosphatase activity as well as low maximums for the duration of the experiment. Cells on implants with a pore geometry of $50 \mu \mathrm{m}, 300 \mu \mathrm{m}, 400 \mu \mathrm{m}$ and $500 \mu \mathrm{m}$ develop identically and reach a maximal activity between days 8 and 12. Alkaline phosphatase activity of cells on $50 \mu \mathrm{m}$ laser-structured surface exceeded that of cells on polystyrene on culture day 12. Cellular alkaline phosphatase activity on the $200 \mu \mathrm{m}$ surface was lower than that on $50 \mu \mathrm{m}$,

\section{Alkaline Phosphatase}

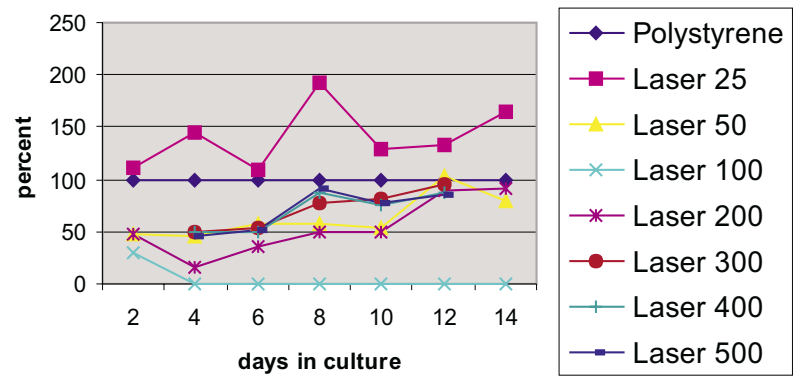

Figure 4. Alkaline phosphatase activity (expressed as a $\%$ of the polystyrene control).

\begin{tabular}{|l|c|c|c|c|c|c|c|}
\hline $\begin{array}{l}\text { Type of } \\
\text { surface }\end{array}$ & Day 2 & Day 4 & Day 6 & Day 8 & Day 10 & Day 12 & Day 14 \\
\hline Polystyrol & 100 & 100 & 100 & 100 & 100 & 100 & 100 \\
\hline Laser 25 & $\begin{array}{c}111(104- \\
113)\end{array}$ & $\begin{array}{c}145(135- \\
155)\end{array}$ & $110(106-115)$ & $192(152-223)$ & $\begin{array}{c}129(116- \\
143)\end{array}$ & $\begin{array}{c}133(131- \\
135)\end{array}$ & $\begin{array}{c}166(159- \\
172)\end{array}$ \\
\hline Laser 50 & $48(31-61)$ & $47(35-58)$ & $57(48-70)$ & $57(46-65)$ & $53(50-57)$ & $\begin{array}{c}103(90- \\
120)\end{array}$ & $79(72-89)$ \\
\hline Laser 100 & $30(30)$ & 0 & 0 & 0 & 0 & 0 & 0 \\
\hline Laser 200 & $48(30-61)$ & $15(0-23)$ & $35(27-48)$ & $50(42-58)$ & $51(46-57)$ & $90(55-115)$ & $91(60-117)$ \\
\hline Laser 300 & - & $50(47-54)$ & $54(45-62)$ & $77(71-83)$ & $82(77-87)$ & $95(95-96)$ & - \\
\hline Laser 400 & - & $50(49-52)$ & $50(47-54)$ & $87(84-90)$ & $76(76-77)$ & $88(84-92)$ & - \\
\hline Laser 500 & - & $45(34-56)$ & $51(45-57)$ & $91(89-93)$ & $77(76-78)$ & $85(81-89)$ & - \\
\hline
\end{tabular}

Table 5. Datasheet corresponding to Figure 4.

$300 \mu \mathrm{m}, 400 \mu \mathrm{m}$ and $500 \mu \mathrm{m}$ surfaces.

Scanning electron microscopy visually confirmed the development of cellular adhesions on the different surfaces. As expected from our cell culture analysis, $100 \mu \mathrm{m}$ surfaces demonstrated almost no capacity for cellular adhesion. Pore "bridging" growth was not demonstrable on $200 \mu \mathrm{m}, 300 \mu \mathrm{m}, 400 \mu \mathrm{m}$ and $500 \mu \mathrm{m}$ porous surfaces (Figure 5). However, scanning electron microscopy demonstrated that on $25 \mu \mathrm{m}$ and $50 \mu \mathrm{m}$ porous surfaces cell growth occurred both with an ingrowth into the pore depth as well as with at least partial bridging of the pores (Figure 6).

\section{Discussion}

The operative technique, the bone - implant interface (implant material, surface geometry, corrosive resistance), the individual immune response, the biomechanics of weight bearing, infection and rare material allergies influence the normal course of integration that occurs at the interface of the implant surface and the bony tissues. As the osteoblast is one of the primary cells involved in osseointegration it is possible to examine by means of cell culture many of the individual biological reactions that occur at the boneimplant interface - stem cell recruitment, cell proliferation, cell differentiation in addition to the extracellular matrix (Clokie and Warshawsky, 1995; Merklein et al., 1998; Morrison et al., 1995). The various culture systems documented in current literature may be classified as follows; primary culture systems (e.g., bone marrow stem cells, intramembraneous bone or trabecular long bone), nontransformed cloned cell lines (e.g. MC3T3-E1), osteosarcoma cell lines (UMR-106, ROS 17/2.8, MG63) and immortalized cell lines (e.g. RCT, HOBIT) from which the 


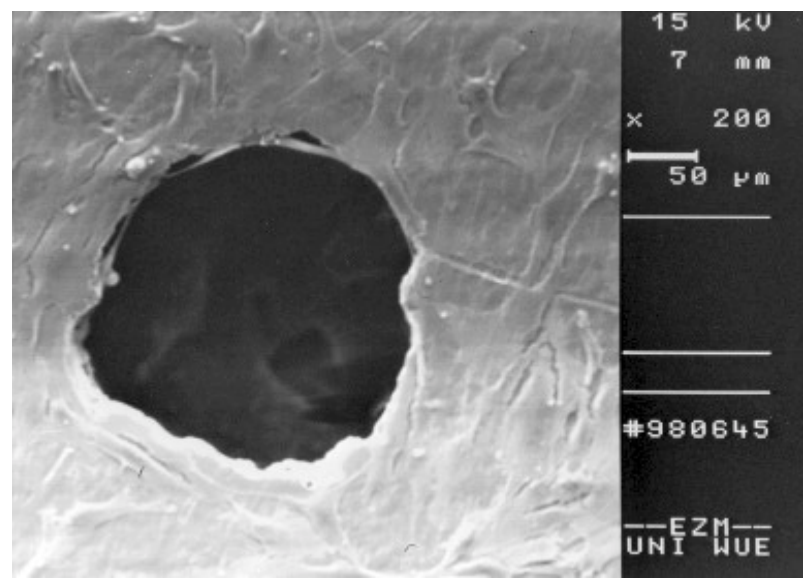

Figure 5. Cellular behavior in culture with the $200 \mu \mathrm{m}$ pores without pore bridging.

hFOB1.19 is derived. The advantage of cell line systems over primary cell culture systems is their reproducibility; the disadvantage, however, is that it is not a natural biosystem. The hFOB 1.19 cell line combines the standardization capability with an osteoblast specific development cycle and therefore the possibility of observation over a time course without the effect of tumor cell specific deregulation.

The osteoblastic response changes significantly with very small porous surface differences (Clark et al., 1990, Martin et al., 1995). On different coated surfaces there is variability in cell specific expression of alkaline phosphatase, fibronectin and collagen (Anselme et al., 1994; Windeler et al., 1991). Bowers and Keller showed that by increasing the surface roughness osteoblastic adhesion increased (Bowers et al., 1992; Keller et al., 1994). In contrast, there are several studies on rat osteoblasts (Meyer et $a l ., 1996)$, from either the MG 63 osteoblast cell line (Martin et al., 1995) or the ROS 17/2.8 osteoscarcoma cell line (Alliot-Licht et al., 1991) or on human osteoblasts (Desantis et al., 1996) where a smooth surface proved better for osteoblast adherence. A positive effect of the surface microstructure (pore diameter of 3-8 $\mu \mathrm{m}$ ) on both osteoblast fixation and number has also been demonstrated (Keller et al., 1994; Qu et al., 1996). A possible explanation for the increased cell growth is that a porous microstructure presents a stimulus to an orientated cell development. In the case of the osteoblast cell lines this effect was demonstrable approximately 20 minutes after incubating the cells on the structured titanium surfaces (Qu et al., 1996). It is certain that the cellular growth of human osteoblasts is superior on titanium surfaces compared with cobalt surfaces (Sinha et al., 1994). By contrast, rat osteoblast growth is better on a cobalt chromium base than on a titanium one (Puleo et al., 1991). It remains uncertain whether the observed differences in cellular growth are influenced by the implant surface roughness, the porous geometry or other specific surface aspects (e.g., oxide layer).

Schwartz described a difference in the cellular response with respect to variations in surface roughness (Schwartz et al., 1997). He postulated that the reduced cell growth observed on smooth surfaces was due to a reduction in surface area and the consequently increased cell death.

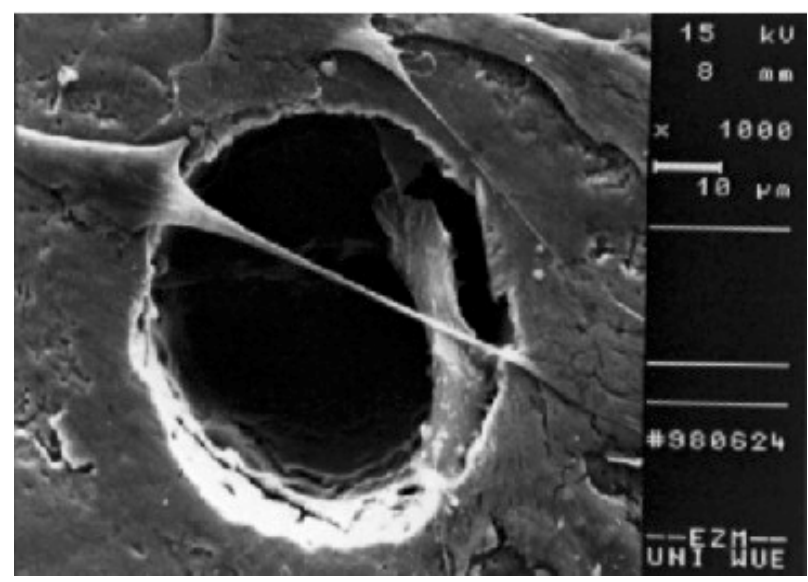

Figure 6. Pore bridging and ingrowth in the pore depth in the presence of the $50 \mu \mathrm{m}$ porous geometry.

Porous surfaces have by contrast a larger culture surface and thereby a lower cell density. On the smooth surface the proliferation was significantly higher in the early phases due to the faster growth. At later time points, as expected, the porous surfaces yield better results (Nöth et al., 1999). Our own cell culture results point to the fact that an increase in surface area is not the deciding regulating factor of cell growth at the bone-implant interface. Osteoblasts in culture with the $200 \mu \mathrm{m}$ porous surface, which had the greatest surface area, had the second lowest level of cell growth. However relative cell viability and alkaline phosphatase expression reached better results. $25 \mu \mathrm{m}$ pores, with medium surface magnification, demonstrated the highest values for relative cell viability and alkaline phosphatase activity.

The second part of this study revealed a time dependent effect on cell viability. According to the observations of Noeth cells in culture with either polystyrene and smooth titanium had an initial high activity. However, porous titanium surface lead to a higher activity than a smooth one from the $10^{\text {th }}$ day in culture (Nöth et al., 1999). In addition, it has been shown that rough cpTi is more favourable than stainless steel or CoCrMo in terms of effect on cellular activity (Merklein et al., 1998). In our study we reaffirmed the time dependency of viability in osteoblasts at the cell-implant interface. The $25 \mu \mathrm{m}$ pore geometry showed the highest activity throughout the study, reaching this at the earliest time point.

Various studies have shown that the synthesis of the extra-cellular matrix and subsequent mineralization are substantially increased on a rough surface material. In contrast however, osteocalcin levels and alkaline phosphatase activity as an indicator of osteoblastic specific activity have been demonstrated to be highest on a smooth surface (Stanford et al., 1994). Lohmann investigated the influence of the rough surface of titanium implants on osteoblast differentiation (Lohmann et al., 1999). He demonstrated that this effect was mediated through PLA2 (phospholipase A2), which regulates the Prostaglandin E2 metabolism. CpTi results in a higher level of alkaline phosphatase activity than either stainless steel (SS) or CoCrMb (Merklein et al., 1998), whereas polished titanium has a higher specific alkaline phosphatase activity than both the 
sand treated and sandtreated-warm handled surface. We have demonstrated the positive influence of a $25 \mu \mathrm{m}$ porous titanium surface when compared with all other surfaces. For our cell line the alkaline phosphatase activity was not only an indicator of increased cell number and cell viability but also provided proof of osteoblast specific activity; osteoblastic alkaline phosphatase being synthesized by all cell types from the pre-osteoblast to the secondary osteoblast (Bruder et al., 1997). The surface-related effect of increased alkaline phosphatase expression and collagen synthesis may be a better indicator of osseointegration. However, the comparison with other cell culture systems is limited as for example fibroblasts and osteoblasts have different sensitivities to material surface modification (Cheung and Haak, 1989; Naji and Harmaond, 1990).

With regard to reports on bony ingrowth, the favorable surface pore sizes reported are in the range from 10 to $500 \mu \mathrm{m}$, although in some studies a border level of $75 \mu \mathrm{m}$ has been identified (Flately et al., 1983; Klawitter and Hulbert, 1971). Homsy (1973) described a $300 \mu \mathrm{m}$ pore size as the most favorable and Pilliar (1987) proposed that a minimum pore size of $50 \mu \mathrm{m}$ be used. Li et al. (1997) suggested that for maximal bony ingrowth a porous surface with pore diameter of $140 \mu \mathrm{m}$ should be used. Schmitz. (1991) demonstrated that using excimer-laser pulsed materials a pore diameter of $40-50 \mu \mathrm{m}$ with a pore depth of $100 \mu \mathrm{m}$ proves maximal cell answer. Porous diameters of $200-400 \mu \mathrm{m}$ have long been preferred and it is suggested that such diameters produce optimal cell migration, adhesion and cellular proliferation (Goshima et al., 1991; Nakahara et al., 1992).

It is obvious from cell culture in vitro studies that an increase in the surface area of the porous surface alone is not responsible for an increase in cellular proliferation, cell vitality or cell synthesis capability. The $500 \mu \mathrm{m}$ porous surface for example, with its lower surface area produces an identical cellular response to those surfaces with pore diameter of $50 \mu \mathrm{m}, 300 \mu \mathrm{m}$ and $400 \mu \mathrm{m}$. An interaction with the surface material itself may explain this observed effect. In our study we confirm the importance of the implant microstructure; however, we demonstrate unexpected findings such as that the $100 \mu \mathrm{m}$ pore surface is extremely unfavorable for cell growth in culture. This result was not predicted as by many authors $100 \mu \mathrm{m}$ is quoted as the border level for pore diameter when considering bony ingrowth in mineralized bone. It is possible that oxidative modifications or variations in oxide thickness may play a role in this response. The heat-effect of laser-treatment may influence the oxide layer (Kilpadi et al., 2000). However, the estimation of the oxide layer modification in the pores is very problematic (Ong and Lucas, 1998).

Scanning electron microscopy offers an explanation for the difference in the cellular parameters described above. Cells cultured with the $50 \mu \mathrm{m}$ porous titanium surface demonstrated a bridging over the pores whereas with a pore diameter of $200 \mu \mathrm{m}$ or more no cellular bridging was observed.

Although a number of statements can be made about the cell-implant interface from currently available cell culture systems we must consider that in interpreting our results we have not included factors such as biomechanical influences, inflammatory parameters, neovascularisation, platelet interaction, the influence of the stem cells or other cells in our system. Method specific limitations such as the influence of FCS in the medium or the specific $\mathrm{NaCl}$ solution used have been previously standardized. However, a density dependent regulation factor on cell growth is possibly relevant. The application of this "interface hypothesis", based on our cellular results, is already on the way being assessed in a comparable animal model.

\section{Conclusion}

The analysis of cell culture results demonstrated that 25 $\mu \mathrm{m}$ and $200 \mu \mathrm{m}$ porous geometries showed results similar to those obtained with the polystyrene control; there was no hint of toxic effects. However, the $100 \mu \mathrm{m}$ porous geometry showed an impressive negative influence on the calculated parameters. The reason for this effect is unclear. The series with $50 \mu \mathrm{m}, 300 \mu \mathrm{m}, 400 \mu \mathrm{m}$ and $500 \mu \mathrm{m}$ showed a similar, intermediate behavior in the cell culture in respect of the calculated parameters, however, worse than the 25 and $200 \mu \mathrm{m}$ porous geometry. In conclusion, the $25 \mu \mathrm{m}$ and $200 \mu \mathrm{m}$ porous geometry seems to have the most positive effect on growth and activity on the human osteoblastic cell line hFOB 1.19.

\section{Acknowledgements}

We would like to thank Dr. A. Lang and Dr. M. Hartmann from AZT-EVUS Co. as well as Dr. U. Holzwarth, Fa. P. Brehm Co., Weisendorf, for their assistance in the production of the laser-structured implants used. Furthermore we would like to thank Dr. Anne Lyons for translating the manuscript.

Funding was obtained from the Bavarian Ministry for Culture in the form of a research grant FORBIOMAT.

\section{References}

Alliot-Licht B, Gregoire M, Orly I, Mentanteau J (1991) Cellular activity of osteoblasts in the presence of hydroxyapatite: An in vitro experiment. Biomaterials 12, 752-756.

Anselme K, Lanel B, Gentil C, Hardouin P, Marie PJ, Sigot-Luizard MF (1994) Bone organotypic culture method: A model for cytocompatibility testing of biomaterials? Cells Mater 4, 113-123.

Bergmann HW, Mayerhofer R, Slunecko T, Hartmann M, Gan E (1994) Improved drilling and cutting with copper vapour lasers. M Proc of CLEO '94. p. 295.

Bergmann HW, Hartmann M, Mayerhofer R, Bartl N (1996). Kupferdampflaser für die effiziente und schädigungsarme Präzisionsbearbeitung von Metallen (Copper vapor laser for efficient precision machining of metals with minimal damage). In: ECLAT '96, Proceedings of the $6^{\text {th }}$ European Conference on Laser Treatment of Materials. Dausinger F, Bergmann HW, Sigel J (eds). Stuttgart. pp. 16-18, 741-750.

Bowers KT, Keller JC, Randolph BA, Wick DG, Michaels CM (1992) Optimization of surface micromorphology for enhanced osteoblast responses in vitro. Int $\mathrm{J}$ Oral Maxillofac Implants 7, 302-310. 
Bradford M (1976) A rapid and sensitive method for the quantitation of micrograms quantities of protein utilizing the principle of protein-dye binding, Anal Biochem 72, 248 - 254.

Bruder SP, Horowitz MC, Mosca JD, Haynesworth SE (1997) Monoclonal antibodies reactive with human osteogenic cell surface antigens. Bone 21, 225 - 235.

Cheung HS, Haak MH (1989) Growth of osteoblasts on porous calcium phosphate ceramic. Biomaterials 10, 63-67.

Clark P, Connolly P, Curtis AS (1990) Topographical control of cell behaviour: II. Multiple grooved substrata. Development 108, 635 - 644 .

Clokie CML, Warshawsky H (1995). Morphologic and radioautographic studies on bone formation in relation to titanium implants using the rat tibia as a model. Int J Oral Maxillofac Implants 10, 155-165.

Desantis D, Guerriero C, Nocini PF, Ungersbock A, Richards G, Gotte P (1996) Adult human bone cells from jaw bones cultured on plasma sprayed or polished surfaces of titanium or hydroxylapatite discs. J Mater Sci Mater Med 7, 21-28.

Flately TJ, Lynch KL, Benson M (1983) Tissue response to implants of calcium phosphate ceramic in the rabbit spine. Clin Orthop 179, 246-252.

Goshima J, Goldberg VM, Caplan AI (1991) The osteogenic potential of culture-expanded rat marrow mesenchymal cells assayed in vivo in calcium phosphate ceramic blocks. Clin Orthop Rel Res 262, 298-311.

Harris SA, Enger RJ, Riggs LB, Spelsberg TC (1995). Development and characterization of a conditionally immortalized human fetal osteoblastic cell line. J Bone Mineral Res 10, 178-186.

Hendrich C, Geyer M, Scheddin D, Schütze N, Eulert J, Thull R (1996a) Ein neues Osteoblasten-Zellkultursystem zur normgerechten Prüfung von Biomaterialien (A new osteoblast cell culture system for standardized testing of biomaterials). Biomed Tech 41, 278-283.

Hendrich C, Trautner M, Geyer M, Thull R, Eulert J (1996b) Eine neuartige Osteoblastenkultur zur biologischen Charkterisierung von Biomaterialien (A novel osteoblast culture for biological characterization of biomaterials). Osteologie 5, 31-32.

Homsy CA (1973) Implant stabilization. Chemical and biochemical consideration. Orthop Clin North Am 4, 295 311 .

Ishiyama M, Tominaga H, Shiga M, Sasamoto K, Ohkura Y, Ueno K, Watanabe M (1995). Novel cell proliferation and cytotoxicity assays using a tetrazolium salt that produces a water-soluble formazan dye. In vitro Toxicology 8, 187-190

Keller JC, Stanford CM, Wightman JP, Draughn RA, Zaharias R (1994) Characterization of titanium implant surface III. J Biomed Mater Res 28, 939-946.

Kilpadi DV, Lemons JE, Liu J, Raikar GN, Weimer JJ, Vohra Y (2000) Cleaning and heat-treatment effects of unalloyed titanium implant surfaces. Int J Oral Maxillofac Implants 15, 219-230.

Klawitter JJ, Hulbert SF (1971) Application of porous ceramics for the attachment of load-bearing orthopaedic applications. J Biomed Mater Res 2, 161-229.
Li J, Liao H, Fartash B, Hermannsson L, Johnsson T (1997) Surface-dimpled commercially pure titanium implant and bone ingrowth. Biomaterials 18, 691-696.

Liu SQ, Saijo K, Todoroki T, Ohno T (1995) Induction of human autologous cytotoxic $\mathrm{T}$ lymphocytes on formalin fixed and paraffin-embedded tumour sections. Nature Medicine 1, 268-271.

Lohmann C, Schwartz Z, Boyan B (1999) Die Effekte der Rauhigkeit von Titanoberflächen und 1,25-(OH) Vitamin D3 auf die Differenzierung von Osteoblasten werden durch die Regulation von Phospholipase $\mathrm{A}_{2}$ und die Aktivierung von Proteinkinase A vermittelt (The effects of surface roughness of titanium and 1,25 $(\mathrm{OH})_{2}$ Vitamin D3 is regulated by phospholipase $\mathrm{A}_{2}$ and the activation of protein kinase A). Z Orthop 137, A93 (abstract).

Martin JY, Schwartz Z, Hummert TW, Schraub DM, Simpson J, Lankford J Jr, Dean DD, Cochran DL, Boyan BD (1995) Effect of surface roughness on proliferation, differentiation and protein synthesis of human osteoblastlike cells (MG63). J Biomed Mater Res 29, 389-401.

Mayerhofer R (1997) Mikromaterialbearbeitung mit Kupferdampflasern (Micromachining of materials with copper vapor lasers). Doctoral Thesis, Technical Faculty, Friedrich-Alexander-Universität Erlangen. pp. 1-145.

Merklein F, Hendrich C, Noth U, Kochinki G, Rader CP, Schütze N, Thull R, Eulert J, (1998) Standardisiertes Testen von Skelett-Implantatoberflächen mit einem Osteoblasten-Zellkultursystem. I Orthopädische Standardmaterialien (Standardized testing of skeletal implant surfaces woth an osteoblast cell culture system. I. Orthopedic standard materials). Biomed Technik 43, 354359.

Meyer U, Szulczewski DH, Möller K, Heide H, Jones DB (1996) Attachment kinetics and differentiation of osteoblasts on different biomaterials. Cells Mater 3, 129140 .

Morrison C, Macnair R, MacDonald C, Wykman A, Goldie I, Grant MH (1995) In vitro biocompatibility testing of polymers for orthopaedic implants using cultured fibroblasts and osteoblasts. Biomaterials 16, 987-992.

Morscher E (1987) Erfahrungen, Anforderungen und Entwicklung von zementfreien Hüftendoprothesen (Experience with, demands and development of cementless hip endoprostheses). Orthop 16, 185-186.

Naji A, Harmand MF (1990) Study of the effect of the surface state on the cytocompatibility of a Co-Cr alloy using human osteoblasts and fibroblasts. J Biomed Mater Res 24, 861-871.

Nakahara H, Goldberg VM, Caplan AI (1992) Cultureexpanded periosteal derived cells exhibit osteochondrogenic potential in porous calcium phosphate ceramics in vivo. Clin Orthop Rel Res 276, 291-298.

Nöth U, Hendrich C, Merklein F, Altvater T, Rader CP, Schütze N, Eulert J, Thull R (1999) Standardisiertes Testen von Skelett-Implantatoberflächen mit einem Osteoblastenzellkultursystem. II. Titanoberflächen unterschiedlicher Rauhigkeit (Standardized testing of skeletal implant surfaces with an osteoblast cell culture system. II. Titanium surfaces with different roughness). Biomed Tech 44, 6-11.

Ong JL, Lucas LC (1998) Auger electron spectroscopy 
and its use for the characterization of titanium and hydroxyapatite surfaces. Biomaterials 19, 455-464.

Pilliar RM (1987), Porous surfaced metallic-implants for orthopaedic applications. J Biomed Mater Res: Applied Biomaterials 21(A1), 1-33.

Puleo DA, Holeran LA, Doremus RH, Bizios R (1991) Osteoblast responses to orthopedic implant materials in vitro. J Biomed Mater Res 25, 711-723.

Qu J, Chehroudi B, Brunette DM (1996) The use of micromachined surfaces to investigate the cell behavioural factors essential to osseointegration. Oral Diseases 2, $102-$ 115.

Schmitz HJ (1991) Optimierung der Oberfläche enossaler Implantate mit Excimer-Laser (Optimization of the surface of enosseous implants with an excimer laser). Habilitations-schrift (Thesis), Rheinisch-Westfälische Technische Hochschule Aachen 4.2.1991, 1-207.

Schwartz Z, Kieswetter K, Dean DD, Boyan BD (1997) Underlying mechanisms at the bone-surface interface during regeneration. J Periodont Res 32, 166-171.

Seewöster Th, Lehmann J (1997) Cell size distribution as a parameter for the predetermination of exponential growth during repeated batch cultivation of $\mathrm{CHO}$ cells. Biotechnol Bioengineering 55, 793-797.

Sinha RK, Morris F, Shah SA, Tuan RS (1994) Surface composition of orthopaedic implant metals regulates cell attachment, spreading and cytoskeletal organisation of primary human osteoblasts in vitro. Clin Orthop Rel Res 305,258-272.

Skalak R (1983) Biomechanical considerations in osseointegrated prostheses. J Prosthet Dent 49, 843- 848.

Søballe K (1993) Hydroxyapatite ceramic coating for bone implant fixation. Acta Orthop Scand Suppl. 255, 158.

Stanford CM, Keller JC, Solursh M (1994) Bone cell expression on titanium surfaces is altered by sterilization treatments. J Dent Res 27, 1061-1071.

Thomas, K.A., Cook S.D (1985) An evaluation of variables influencing implant fixation by direct bone apposition. J Biom Mat Res 19, 875-901.

Windeler AS, Bonewald, L, Khare AG, Boyan B, Mundy GR (1991) The influence of sputtered bone substitutes on cell growth and phenotypic expression. In: The Bone-Biomaterial Interface. Davies JE (ed). Univ Toronto Press, Buffalo. pp. 205-213

\section{Discussion with Reviewers}

A. Wennerberg: When preparing a titanium surface with laser, the oxide thickness and structure will be altered, how has this been controlled? It is possible that the differences in oxide structure contributed to the results?

Authors: Yes, we agree completely, that oxide thickness is important. We expect a rather thick oxide. However, the measurement of the oxide thickness at a certain time point was not done. According to the literature the oxide thickness should be around 2-6 nm. Because of the thermal laser treatment the oxide thickness was probably increased (Kasemo and Lausmaa, 1983, Larsson et al., 1994, Lausmaa et al., 1990)
R.G. Richards: The authors mention that ALP activity indicated increased cell number and vitality and provided proof of osteoblastic specific activity? The last point is questioned since fibroblasts are also known to have ALP activity. Please comment.

Authors: Control measurements in our laboratory with BALB/3T3 fibroblasts demonstrated that alkaline phosphatase activity was less than $5 \%$ of the alkaline phosphatase activity of the osteoblast.

R.S. Tuan: It should be noted that MTT is in fact generally used as a means for determining cell number, given that mitochondrial activity is relatively constant among cells. If that were the case, the MTT data will resemble somewhat the cell data, provided the latter is done correctly. At the least, assuming the cell numbers are correct, then the MTT data should be normalized to cell number, if the authors indeed wish to use the MTT activity as a parameter for ,cell viability“. A better way would be to measure metabolic leucine incorporation, for example for protein synthetic activity. This issue is very problematic.

Authors: The MTT data are now normalized to cell number. The WST-test correlates with the electronic count. In the meantime the WST-1 Test is used in different cells. To our knowledge the WST test was used to check the GT3TKB cellsystem (Liu et al., 1995), the fetal rat liver parenchymal cell (Gressner et al., 1996), the HI-60 cells (Takenouchi and Munekata, 1995), Rat C6 glioma cells (Iwaki et al., 1995), and BKH-21 cells (Yano et al., 1994). We have performed a check for correlation between cell number and WST in the exponential growing phase, which resulted in a Pearson value of 0.994 and a one-sided significance of 0.003 . WST seems to be a little bit more sensitive than XTT. However, it is correct, that it was much more easier to use the WST-Test (less cytotoxic, less mistakes, shorter incubation time) (Ishiyama et al., 1995). Metabolic leucine incorporation was not measured.

\section{Additional References}

Gressner AM, Polzar AM, Lahme B, Mannherz HG (1996) Induction of rat liver parenchymal cell apoptosis by hepatic myofibroblasts via transforming growth factor beta. Hepatology 23, 571-581.

Iwaki T, Iwaki A, Fukumaki Y, Tateishi J (1995) Alpha B-crystallin in C6 glioma cells supports their survival in elevated extracellular $\mathrm{K}^{+}$: the implication of a protective role of alpha B-crystallin accumulation in reactive glia. Brain Res 673, 47-52.

Kasemo B, Lausmaa J (1983) Biocompatibility of titanium implants. Surface science aspects. J Prosthet Dent 49, 832-837.

Larsson C, Thomsen P, Lausmaa J, Rodahl M, Kasemo B, Ericson LE (1994) Bone response to surface modified implants: studies on electropolished implants with different oxide thickness and morphology. Biomaterials 15, 10621074.

Lausmaa J, Kasemo B, Mattsson H (1990) Surface spectroscopic characterization of titanium implant materials. Appl Surf Sci 44, 133-146. 
Takenouchi T, Munekata E (1995) Trophic effects of substance $\mathrm{P}$ and $\beta$-amyloid peptide on dibutyryl cyclic AMP-differentiated human leukemic (HL-60) cells. Life Sci 56, 479-484.
Yano T, Teruya K, Shirahata S, Watanabe J, Osada K, Tachibana H, Ohashi H, Kim EH, Murahami H (1994) Ras oncogene enhances the production of a recombinant protein regulated by the cytomegalovirus promoter in $\mathrm{BKH}-$ 21 cells. Cytotechnology 16, 167-178. 